\title{
Coming to terms with genocidal pasts in comparative perspective: Germany and Australia
}

\author{
A. Dirk M oses
}

The question of how countries deal with the material and symbolic legacies of totalitarian rule, genocide, and civil war in their immediate pasts is spawning a growing body of research on recent national and regional cases - post-apartheid South Africa, postcommunist central and eastern Europe, and post-dictatorial South America - as well as on the 'classic' instances of postwar Japan and Germany. ${ }^{1}$ Closely related is the voluminous literature on collective memory, much of which studies the impact of trauma on cultural and political group identity. ${ }^{2}$ Nowhere is the connection between genocidal pasts and collective memory more evident than in the Federal Republic of Germany, which is widely recognized as the paradigmatic case of what there is called a successful V ergangenheitsbewältigung or A ufarbeitung der $V$ ergangen heit - the 'mastering', 'working through', or 'coming to terms with' a national history dripping with the blood of civil war and genocide. In this instance, in an appropriate symmetry, it is the paradigmatic case of genocide - the systematic murder of millions of Jews, Gypsies, homosexuals, mentally disabled, and other groups. In Germany, 'coming to terms with the $\mathrm{N}$ azi past' is a key element in the development of its democratic and liberal political culture after $1945^{3}$

The question is not of mere academic interest: it goes to the heart of the self-understanding of countries where genocide taints their histories. What of such a discourse in A ustralia? Since the publication over the past quarter century of substantial research on nineteenth century frontier violence, and more recently, of the Bringing Them $\mathrm{H}$ ome report on the forcible removal of Aboriginal children from their families, talk of genocideis in theair. ${ }^{4}$ Yet, many A ustralians object that it is not a term relevant to the history

1. Adam 2001, Barkan 2000, Baruma 1994, McAdams 1997, Minow 1998, Schwan 2001, Villa-Vicencio and Verwoerd 2000.

2. In the place of numerous citations, see Hirsch 1995, and the analyses by Olick and Robbins 1998, Olick 1999 and Klein 2000.

3. Olick and Levey 1997. The authors al so stress the importance of this process for West Germany's international credibility.

4. Gaita 1999, Manne 1999, van Krieken 1999, M oses 2000. A genocide debate has been gaining momentum since the 1980s when Bernard Smith (1980: 52) in his Boyer Lectures, said that Australians had been 'caught out as it were red-handed playing the genocide game'; cf. Duncan 1985, Wilson 1985; Tony Barta's 1987 intervention is the first systematic treatment of the issue in the scholarly literature. Cf Barta 1985. The most recent contribution is Reynolds 2001b. 
of their country, and they hold a post-genocidal reckoning to be unnecessary, even mischievous and divisive. ${ }^{5}$ Moreover, the conservative and right-wing opponents of the genocide concept contend that it is a weapon deployed by a 'new class' of left-liberal intellectuals to establish (or reinforce) its supposed cultural hegemony. The debate has now reached a stalemate with rival factions of the intelligentsia now disputing the very facts of Australian history.

This article argues that the process of 'coming to terms with the past' in Australia can be productively stimulated by considering the German experience with which it has important similarities as well as differences. But before analysing each case in turn, it is necessary to refer to the relevant literature in anthropology and the sociology of knowledge to clarify the issues underlying the public-intellectual struggles that comprise Australia's 'culture wars'.

\section{$\mathrm{N}$ ational origins, symbolic capital, and the perpetrator trauma}

The issue at stake is the nation-building project, which requires mythic origins (cosmogenies). Such origins are necessary for nation-building because they permit the 'narration of the nation' by conjuring the illusion of a 'continuous narrative of national progress' that renders natural the construction of 'a people' by obscuring the contingent and artificial nature of that construction. ${ }^{6}$ As Etienne Balibar points out, 'The myth of origins and national continuity ... is ... an effective ideological form, in which the imaginary singularity of national formations is constructed daily by moving back from the present into the past'. ${ }^{7}$ Moreover, cosmogenies are used to repair the social fabric. Thus, in relation to traditional societies, Mircea Eliade identified their function in providing models of exemplary conduct that could be reiterated to 'create the world anew' when group decline was perceived or social healing was required. Despite obvious differences between such societies and the modern world, Eliade's observation contains a telling insight. Members of nation-states may not invest their rituals and myths with supernatural powers, but its origins are sacred nonetheless because 'in one way or another one "lives" myth, in the sense that one is seized by the sacred, exalting power of the events recollected or re-enacted'. ${ }^{8}$ 'Coming to terms with the past' disables this integrative power by linking the nation's origins to catastrophes, like genocide and civil war, in its recent past.

But who mobilises this discourse? Conservatives claim that the privileged, left-liberal academic elite in the universities purveys guilt and shame about the past to its own advantage. Is this true? Sociologists like Alvin Gouldner used the term 'new class' to refer both to the technocrats that administer modern capitalism and to the humanistically-oriented cosmopolitan intelligentsia that tries to establish its influence by setting the moral and symbolic agenda of the nation's collective consciousness. ${ }^{9}$ Similarly, Pierre Bourdieu argues that the leftist intelligentsia comprises the dominated faction of a dominant class in which bourgeois elites hold sway. ${ }^{10}$ In terms of his elaborate theory

\footnotetext{
5. Clendinnen 2001.

6. Bhaba 1990: 1; Attwood 2000.

7. Balibar 1991: 87. Bain Attwood 1996 has made a similar argument.

8. Eliade 1963: 19

9. Gouldner 1979.

10. Bourdieu 1984: 120. Cf. Milner 2000.
} 
of capital (economic, social, cultural, symbolic) and social class, he maintains plausibly that both sectors of the dominant class engage in struggles with one another for symbolic capital to define, and thereby make, social reality. ${ }^{11}$ But the motivation and actual role of the subordinate intelligentsia in power struggles remains unclear. ${ }^{12}$ In fact, because symbolic capital is the means by which direct forms of domination by other capitals are obscured, and is therefore a derivative rather than an autonomous power in its own right, Bourdieu discounts the analysis of ideologies in themselves. ${ }^{13}$ Yet, while the respective positions of rival factions of the intelligentsia in the intellectual field are obviously relevant considerations, his theory needs to be complemented by an account of the powerful emotions and ideological commitments that drive intellectuals.

In order to understand the ideological heat in debates about national origins, it is necessary to turn to the concept of 'perpetrator trauma' developed by Cathy Caruth, Richard Bernstein, and Jan Assmann with reference to Freud's M oses and monotheism. A fter the Israelites murdered Moses, they reverted initially to their old polytheistic religion, only later turning to Moses's monotheism. The trauma was experienced by the descendants of the perpetrators when they realised the crime their ancestors had committed. Caruth uses this idea to suggest that perpetrator trauma is delayed or latent, because at the moment of the deed the subject does not realise what it is doing. Subsequently, the perpetrator-collective suffers 'traumatic recall' as the deed, which is only constituted as such in public memory, enters the consciousness of the population. ${ }^{14}$ And the perpetrator trauma continues to haunt the perpetrator-collective until it becomes narratable into a new legitimating story and constitutes part of its selfunderstanding.

In this article, I arguethat the perpetrator trauma is at once the source of indignation experienced by some intellectuals at the suffering inflicted by the collective to which they belong, and the mechanism by which they liberate themselves from domination by the technocratic bourgeoisie and national-conservative intel lectuals. I argue, further, that the critical public discussion this liberation unleashes about national origins is instrumental in the political humanisation of the polity, which hitherto has been in thrall to the legitimating myths of the national-conservative intellectuals. ${ }^{15}$ Yet the moral sensitivity that drives left-wing intellectuals can mean that it develops legitimating myths of its own. Consequently, it is necessary to distinguish the senses in which 'coming to terms with the past' is used. On the one hand, it is referred to as a process of honest and critical reckoning with a tainted national past. On the other, it is often used as a partial and moralistic discourse

11. Bourdieu 1987: 13f.

12. Bourdieu's argument even becomes circular and appeals positivistically to 'real ity' as a limit to the classificatory ambitions of intellectual groups: 'In the struggle to make a vision of the world universally known and recognized, the balance of power depends on the symbolic capital accumulated by those who aim at imposing the various visions in contention, and on the extent to which these visions are themselves grounded in reality'. Bourdieu 1987: 15. See also Bourdieu 1989.

13. Bourdieu 1998: 47, Bourdieu 1977: 188. Mark Davis's 1999 perceptive study of Australian cultural elites, Ganglands, makes a similar argument to Bourdieu, contending that intellectual rivalry can be explained along generational lines.

14. Bernstein 1998, Caruth 1995, Assmann 1997, 1999. See LaCapra 2001 for a discussion of history and trauma in general. 
by oppositional intelligentsia in its struggle for symbolic capital in the intellectual field. Usually, leftist intellectuals will link the two senses of the term by claiming to be agents of the overarching process, thereby equating political humanisation with their domination of symbolic politics and influence in policymaking. The West German case, however, shows that political-moral progress is a by-product of a public sphere, in which critical reason functions, which means that neither faction of the intel ligentsia is able to dominate the other.

\section{The creation of a G erman 'self critical community'}

The Federal Republic had two myths of origin: the moral legitimacy of the republican foundation in 1949, and the viability of German national identity itself. The former was more important for liberals, the latter for conservatives. Although many conservatives were not enamoured of the new Federal Republic's parliamentary liberalism in 1949, the intensity of the cold war in the Federal Republic meant that liberals and conservatives shared an anti-Communist orientation that affected their 'answer' to the Nazi past. For both limited their reckoning with the past to legal and constitutional matters, prosecuting war criminals (tempered by generous amnesties in the 1950s), paying reparations to Israel, and banning extremist parties on the left and right. Although liberals were by no means aggressive nationalists, even they did not want to abandon a sense of positive continuities with the German past. After all, they represented the liberal parliamentary traditions that could be traced to the first half of the nineteenth century. Conservatives, for their part, did their utmost to disentangle Nazism from German traditions by blaming the left and mass democracy for the plebeian Hitler who was, they insisted, a socialist of sorts. They did not deny the Nazi crimes, but laid the blame for their commission at the feet of 'modernity' rather than their cherished nationalist tradition. The answer to the Nazi past was to maintain pride in positive German national traditions and its latest garb, the anti-Communist Federal Republic.

Leftist critics attacked both these myths of origin. First, they argued that, because the course of German history had culminated in Nazism and organised mass murder, national traditions were irredeemably tainted. Consequently, they urged radical economic and political change along democratic socialist lines. Second, when these hopes were dashed by foundation of the Federal Republic in 1949, they indicted it as a 'restorationist' regime whose continuities with the $\mathrm{N}$ azi system were as significant as the differences, if not more so. ${ }^{16}$ It was no coincidence, they averred, that many erstwhile Nazis had found a comfortable home in West Germany. ${ }^{17}$

Typologically, such critics were oppositional, cosmopolitan intellectuals who were moved by shame and indignation for what their countrymen and women had done.

15. Although narratives of such progress are unfashionable, indeed, inexplicable for many intellectuals, when seen in light of Germany's moral collapse in the N azi years, the Federal Republic's political humanisation is readily apparent. Foucault is often cited as authority for the proposition that regimes of truth replace one another without moral progress, yet his own 'What is enlightenment' shows that in fact he did believe in the hypergood (Charles Taylor) of human autonomy and that he saw important gains for this ideal in postwar Europe. Foucault 1984: $46 f$

16. Wippermann 1976.

17. Barta 1989, Habermas 1996, Frei 1999. 
They were the agents of traumatic recall in the Federal Republic, sentinels of H olocaust memory and solidarity with the countless victims of Germans. ${ }^{18}$ Ever suspicious of perceived fascist continuities, they began the 'culture of vigilance' - critics called it 'alarmism' - against perceived backsliding into 'bad old German ways' in culture and politics.

Their project also entailed remaking German subjectivity. Heavily influenced by A lexander and Margarete Mitscherliches' socially-applied psychoanalysis, as well as by theories of mass culture and fascism of the recently returned Frankfurt School, the oppositional intelligentsia developed an emphatic post-national, even anti-national, subjectivity. For the problem was not only capitalism, but also the specifically German cultural pathologies of the 'authoritarian personality' and underdeveloped, weak ego that sought compensation in strong leadership and the collective security (the WirG efühl: 'we feeling') of group identity. ${ }^{19}$ The main thesis of the Mitscherliches' famous book, The inability to mourn (1967), was that West Germans were caught in a debilitating melancholia, as they were unable to mourn for, and thereby work through, the narcissistic collective love objects of Hitler and the German nation. Melancholia, or depression, was the poisoned fruit of a blocked mourning process, which, if successfully negotiated, released the subject from its libidinal fixation on the love object and permitted a new investment to be made. In the postwar context, the Mitscherliches were appalled by the continuing nationalist orientation of West Germans they thought was preventing them from engaging in antifascist politics and democratic socialist reconstruction. 'The inability to mourn' became the prime explanatory device by which the German left proclaimed its post-national credentials and with which it sought to reconfigure the subjectivities of other West Germans.

The fascinating feature of the West German confrontation with the $\mathrm{N}$ azi past is not only how this minority position became institutionalised in public memory and inscribed in personality structures by the 1990s, but al so its twisted path and the attenuated manner in which it occurred. For unlike recent explanations that stress the victory of the dissident wing of the intel ligentsia, ${ }^{20} \mathrm{a}$ kind of compromise between the warring factions in fact has been reached. This process becomes explicable by examining two aspects of this institutionalisation. The first is generational change. The post-national subjectivity became the norm for the majority of the most celebrated postwar political generation, the sixty-eighters, born in the 1940s and therefore in lesser need of the integrating power of founding myths of Federal Republic than their 'nazified' parents. ${ }^{21}$ Because they regarded N azism as archetypically German, their loyalty moved to universal values, which Jürgen Habermas, the most significant theorist of this orientation, celebrates as the fruit of a post-conventional (ie post-national) identity. ${ }^{22}$ In their profound alienation from the national culture and institutions of West Germany, they

18. Geyer 1996.

19. Mitscherlich 1975 (English edition). I discuss the theory in Moses 1999; see Jay 1973 for the Frankfurt School and psychoanalysis. Moeller 1996 and Maier 1993 challenge the thesis that the 1950s were years of silence about the Nazi past.

20. Geyer 1996, Albrecht et al. 1999.

21. Marcuse 1998. Marcuse's new book (2001) is an indispensable analysis and survey of post-war West German reckoning with the Nazi past.

22. Habermas 1990; the sociologist Bernard Giesen calls it a 'H olocaust identity': Giesen 1998. 
exhibited the main symptoms of the perpetrator trauma. Their sympathies lay not with their compromised parents and their national tradition, but with the victims of $\mathrm{N}$ ational Socialism.

This transfer of loyalties, however, did not signal a balanced or healthy posture towards the past. For in the 1970s, these victims were not necessarily Jews. In fact, the militant anti-Zionism and anti-A mericanism ('USA =SA SS') of the sixty-eighters (and by extension, the German left) meant that they saw communists and workers as the Nazi regime's prime targets. ${ }^{23}$ And by facilely identifying themselves with these victims to avoid the moral pollution bequeathed to them by their parents, some sixtyeighters joined the terrorist 'armed struggle' against the 'fascist' West German state, committing dozens of murders al ong the way, while many others of their generational cohort sympathised with the cause. ${ }^{24}$ Their sour reaction to the collapse of East Germany in 1989-90 showed that many sixty-eighters still hoped that the German Democratic Republic could have moved in a democratic socialist direction rather than join the West. As some commentators wryly noted, it was now the turn of the sixtyeighters to mourn for the love object of a united socialist Germany ${ }^{25}$ The destruction of the national-conservatives myths of origin by the perpetrator trauma does not mean that the bearers of the trauma necessarily have the 'answer' to the riddles of history.

Because of such excesses in the 1970s, many liberals who had been reformers in the previous decade entered into an alliance with conservative professors and intellectuals, decrying the 'new elite' that had entered the universities, schools and media and had supposedly taken control of the country. ${ }^{26}$ Until the 1980 s, Holocaust memory remained undetermined as the leftist intelligentsia rethought the meaning of the past and posture towards Israel, while liberals and conservatives waged trench warfare against them on university committees. In the context of the cold war, however, the left's main weapon remained the claim of the uniqueness of the Holocaust, because it entailed the bankruptcy of the national ideal and implied the country's negative myth of origin. And debates about the H olocaust are always also debates about the viability of a German national identity as the well-known historical controversies of the 1980s and 1990s show: the Historians' Debate of 1986, the Goldhagen Debate of 1996-97, the discussion on the travelling exhibition on the war crimes of the German Army and on the Berlin Holocaust Memorial in the late 1990s. ${ }^{27}$

Consequently, when Helmut Kohl's conservative Christian Democrats returned to power federally in 1982, they proclaimed a 'spiritual-moral change' (geistige-moralische Wende) to make good the damage the 'the intellectuals' had inflicted on the national fabric. Instead of 'emancipation' they preached 'identity', and conservative historians

23. Diner 1993: 117ff, Marcuse 2001: 13. The German Democratic Republic claimed to havemadea clean break with the nationalist past, and having smashed the capital ist substructure of fascism, it did not have any N azi continuities with which to reckon. For this reason, it could, with a good antifascist conscience, help train Pal estinian terrorists and condemn the Federal Republic as an irredentist state. See Herf 1997.

24. Moses 1998b

25. Lewis 1995, Müller 2000.

26. Wipperman 1976, Schelsky 1975, Sontheimer 1976, Muller 2000.

27. Maier 1998, Wiedmer 1999, Herbert 1999, Moses 1998b, Eley 2001, Bosworth 1993, Heer and Naumann 2000. 
made the same moves by challenging the new language of the uniqueness of the Holocaust that the cosmopolitan intelligentsia was beginning to institutionalise in the public sphere through prominent left-liberal newspapers. ${ }^{28}$

Yet the neo-nationalist campaign ultimately failed, most notably in the 'Historians' Dispute' and Bitburg affair of the mid-1980s, because liberal intellectuals sided with leftists like Jürgen Habermas. In their view, the neo-conservative instrumental isation of the past for contemporary nationalist cultural politics was immoral and threatened to revive illiberal mentalities by its discursive affinities with far-right ideologues and movements. They attacked this defence of national myths of origin as 'relativising the H olocaust', 'normalising the past', and 'apologetic'. ${ }^{29} \mathrm{As}$ a result of this new left-liberal alliance, the Holocaust has since become anchored in the Federal Republic as a negative myth of origin, its new source of historical legitimacy. Two hundred and fifty sites of Holocaust mourning now exist there, and a football-field-sized memorial to murdered European Jewry will soon be constructed next to the Reichstag and Pariser Platz in Berlin. As Jan Assmann observed, 'As a perpetrator trauma, Auschwitz is a latent experience. After the "material reality" of the facts became known immediately after the war, the "historical truth" needed decades to sink into general consciousness and find appropriate forms of remembrance' ${ }^{30}$

Does this mean that the humanistic intelligentsia has prevailed? Have Germans now engaged in the Trauerarbeit - the work of mourning urged by the Mitscherliches - and detached themselves from their collective narcissism? Superficially, it appears as if they have. The leftwing of the political class remains committed to universal values and is suspicious of 'national interests', and its collective pride rests on the perception of having successfully expedited the generational mission to remake German subjectivity and institutionalise a kind of tempered antifascism. ${ }^{31}$

To be sure, the perpetrator trauma is essential to rupture the continuity of national traditions by pointing out the criminality or ambivalence of the country's origins. But this is only part of the story. The discourse of 'mastering the past' is a necessary but insufficient condition for political humanisation. Because political and moral communities are necessarily concrete and possess a diachronic consciousness, the abstract universalism of the German left and the radical historical rupture it entreats could never command a minimum consensus in the public sphere. The other key factor, then, is the al liance between leftist and liberal intel lectuals against the conservative-nationalist intelligentsia, because it permits the combination of the moral energy of the perpetrator trauma with the commitment to the country's historical institutions that the liberals represent.

Relevant here is the fact that liberals tend to employ the language of shame to refer to German crimes, while the left uses the language of guilt. ${ }^{32}$ The former implies the continuity of the German cultural nation, while the latter, in an analogy with the psychoanalytic procedure of working through, is indentured to a protocol of redemp-

\footnotetext{
28. Maier 1988.

29. Olick 1998.

30. Assmann 1999.

31. N aumann 2000.

32. Schaap 2001.
} 
tion that issues in a radical new identity. The liberal language of shame and regret secures this continuity. Michael Walzer calls such a liberal universalism 'reiterated' rather than abstract, because it is located within the national narrative that has been purged of its potential criminality by the mediation of critical reflection. Cosmopolitanism becomes anchored in the subjectivities and structures of the society, and its citizens become rooted cosmopolitans, or 'cosmopolitan patriots', as Anthony Appiah has recently advocated. ${ }^{33}$

If one side cannot impose itself, how does the public sphere function? By referring current problems to the perceived pathologies of the nation's history, it is the space in which inherited traditions and discourses, as well as political, economic, and social structures, are scrutinised in light of universal principles. Since the war, Germans have thrashed out the contested lessons of their past. A minimum consensus about the past, and therefore the present and future nature of German democracy, started to develop when both sides relativised their absolute positions. In the 1980s and 1990s, the left slowly gave up its dreams of a 'third way' between socialism and capitalism and began to desist from using the Holocaust to attack the foundation of the 1949 republic, so liberals and conservatives could accept the commemoration of the Holocaust as the legitimating origin of the polity, which is henceforth constituted as an anti-genocidal moral community and inheritor of positive German traditions. A 'self-critical community' (Homi Bhabha) emerges in which the open debate about the meaning of the past provides the orientation in the present and a guide for the future. ${ }^{34}$

No one perspective on the past, then, whether nationalist or anti-nationalist, affords a privileged perspective, conclusive answer, or knockdown argument. Rather than the narrative closure implicit in absolute claims to 'master' or even conclusively 'come to terms with the past', the comportment to history I claim to see in the German case is a continuous process of considering the various meanings of a genocidal past and what should be done about it. This is democracy based, not on an uncritical national continuity, nor on abstract norms that entail a temporal rupture and refoundation of the polity, but on the operationalisation of what the 'Sydney School' of political and legal philosophy calls 'critical public reason' and the 'jurisprudence of regret'. ${ }^{35}$ What is noteworthy about such regret is its recognition that this process is an openended, critically hermeneutical relationship to national traditions. As the American legal philosopher Gerald Postema notes, 'This is prophetic memory, forcing the nation to take an honest, inclusive look at its past, forcing it to face its hypocrisy. The power of this criticism comes precisely from this fact that the principles it appeals to are historically grounded in the nation'. ${ }^{36}$

\footnotetext{
33. Appiah 1997.

34. Bhabha 1998.

35. Ivison 2000, Webber 1995, Patton 1995.

36. Postema 1991: 1180. For the 'politics of regret', see Olick and Coughlin, forthcoming.
} 


\section{A ustralia's 'history wars'}

Not for nothing have A ustralia's 'history wars' been called a 'foundational dispute', ${ }^{37}$ Comparison with Germany reveals significant similarities and differences between the two cases.

Let us begin with the former.

\section{The similarities}

1 The Australian leftist intelligentsia also articulates the perpetrator trauma by consistently highlighting the dark aspects of the country's past. No less a figure than Manning Clark observed in the bicentennial year that 'Our history is in danger of degenerating into yet another variation of oversimplification - a division of humanity into "goodies" and "baddies"', although he clearly wel comed this 'radical literature' to counter the prevailing conformist and triumphal ist national ist tel eology. ${ }^{38} \mathrm{Clark}$ 's intervention, as one observer noted recently, 'was a piece over which the Liberal Party are still smarting', because it called on Australians to 'gain wisdom' by recognising the evil that lay at the heart of their country's foundation, namely, the evil visited upon the A borigines, the convicts, and the environment. ${ }^{39}$ Although Clark did not criminalise the entire Australian past per se, the balance of his case was very much at the critical end of the spectrum, ridiculing mercilessly as he did the cherished ideals of Australian conservatism. For the 'myth about the beneficial role of British civilization' needed to be ruptured, he pleaded, so A ustralians could 'choose what we like from the baggage train of our past, and take what we want into the future'. ${ }^{40}$ The country's origin, far from heroic, was poisoned. Clark's was a call, in effect, to start again, to refound the country.

2 As in Germany, the left gained a presence in the institutions of cultural transmission, especially the universities. More so than Germany, however, such advances in the intellectual field were conferred with official legitimacy. The then Labor Party Prime Minister, Paul Keating, and his speech-writer, the historian Don Watson, were highly sensitive to race issues, and in 1992 Keating delivered his so-called 'Redfern Speech' in which he publicly avowed 'our' (ie European-Australian) responsibility for the lethal practices and policies towards Aborigines in the past. ${ }^{41}$ The contemporaneous Mabo judgement reinforced the new public language with the much-quoted words that the dispossession of the A borigines was 'the darkest aspect' of Australian history that had bequeathed a legacy of 'unutterable shame'. Mabo represented a fundamental challenge to the national ist-conservative myth of white settlement. ${ }^{42}$

3 The response of conservative intellectuals was also reminiscent of their German counterparts. In terms very much like Helmut Kohl when he came to power in 1982, John Howard and right-wing intellectuals sought to repair the damage they perceived to have been done by the cosmopolitan intellectuals and the Labor Party after the Coalition won the Federal election in $1996 .{ }^{43}$ And, as in Germany, a victory for the

\footnotetext{
37. Beilharz 2001: 68.

38. Clark 1988: 13.

39. McKenna 1997: 18.

40. Clark 1998: 12, 15.

41. Keating 1995, Watson 2000.

42. Attwood 1996.
} 
conservatives was accompanied by mobilisation further to the right in the form of Pauline Hanson and her One Nation Party.

In order to understand the conservatives' reaction, it is necessary to appreciate their sense of impotence in the public sphere, a syndrome acutely analysed by Ghassan Hage, who calls their political language a 'discourse of decline' that reflects a real loss of symbolic power. ${ }^{44}$ As in the controversy over Asian immigration in the 1980s, the historian Geoffrey Blainey has provided the coalition parties with the analysis and metaphors it uses to challenge the left's definition of public language regarding A boriginal issues in the 1990s. Unlike some, he does not deny the reality of frontier massacres and dispossession but seeks to disable the left from blaming the British in a criminal manner by setting the conflict in a world-historical context. In a similar way, the German historian Ernst Nolte hoped to take the sting out the leftist claim about the Holocaust's uniqueness. Where for Nolte the dialectic of revolution and counter-revolution unleashed in 1789 was the world-historical drama in which Germany merely played a role, for Blainey the real action was the 'unique confrontation in recorded history' of British modernity and its system of land use, and the Aborigines with their incompatible culture. It was not a matter, then, of evil, avaricious Britons vanquishing the innocent, peaceful, and ecologically responsible natives, but an unavoidable, even tragic chapter of world history. ${ }^{45}$

Because Blainey is too clever and sensitive to deny the suffering inflicted by whites, it needs to be balanced by white suffering and redeemed by a greater good. ${ }^{46}$ This theodicy is Australian civilisation itself. In a century of totalitarian genocide and mass killing, A ustralia was one of the few countries to retain its democratic system of government; its brutal ly harsh environment was rendered viable and prosperous by the Europeans, its farms fed millions beyond its shores. It is 'one of the world's success stories'. Consequently, Australians can be 'proud' (rather than ashamed) of their national achievement. ${ }^{47}$ This is the argument with which modern conservatism reformulates the myth of origin to see off the critical scholarship of the last generation. 'I do not feel it is accurate or fair to portray Australia's history since 1788 as little more than a disgraceful record of imperialism, exploitation, and racism', Prime Minister John Howard wrote recently. 'Such a portrayal is a gross distortion, and deliberately neglects the overall story of great Australian achievement that is there in our history to be told' ${ }^{48}$

Rescuing this theodicy has meant that the conservative government colludes with conservative intellectuals, just as Kohl's government did in the 1980s. Most recently, it takes the form of the intriguingly named 'Bennel ong Society', formed in 2000 by figures around the Q uadrant magazine and senior government and former ministers to influence public opinion and policy debates. Part of their manifesto is to ensure that 'decent respect be shown to individuals, religious bodies and governments in Australia who

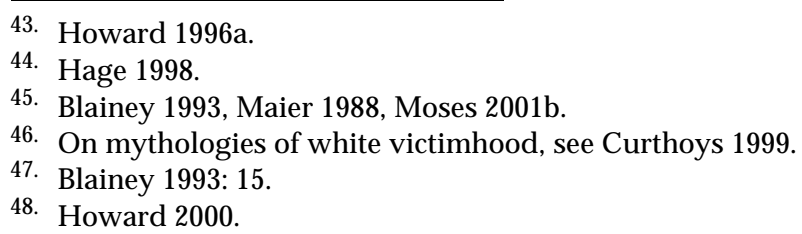


have tried to share with A borigines what they thought were the best things in their way of life'. ${ }^{49}$

4 The genocide issue has become the functional equivalent of the uniqueness of the Holocaust in Germany: the blemish that soils the myth of origin by preventing it from doing the magic work of social integration and healing. Just when it appeared that conservatives thought they had regained control of the historical and national agenda in the mid-1990s, their complacency was shattered by a spectacular instance of traumatic recall, the Bringing Them H ome report on the Stolen Generations in 1997, which also received considerable international attention, including screaming headlines in Germany of 'A ustralia's Holocaust'. ${ }^{50}$ The return of the repressed came not in the form of records of frontier violence, but in the largely twentieth century phenomena of eugenicist and assimilationist programmes in which thousands of 'mixed-blood' A boriginal children were forcibly removed from their families. What is more, the report argued that even the postwar assimilation policies were genocidal in terms of the United N ations Convention on the genocide.

Conservative commentators were quick to identify the meaning of this accusation. Ron Brunton of the far right Institute of Public Affairs averred that 'the genocide "finding" has been greeted with joyous acclaim by those people in the universities, churches, and other usually suspect institutions who know in the depth of their bowels that Australia is bad'. ${ }^{51}$ In other words, it threatened to cede symbolic power back to the rival intelligentsia and undermine, once again, the national myth of origins, especially since the removal policies were expedited in the name of Australian civilisation. ${ }^{52}$ Brunton himself made the link between genocide and national viability explicit: "If Australia is to maintain its dignity as a nation, it cannot afford to have a second "genocide" finding made against it'. ${ }^{53}$ A nother Institute of Public Affairs contributor, Patrick M organ, articulated the same fear: 'The adversary view of Australia undermines belief in our nation and deprives us of a raison d'être - it causes internal collapse from pointless guilt and remorse' . ${ }^{54}$ The Bringing Them H ome report, a newspaper columnist complained, was a piece of 'cultural defamation'. ${ }^{55}$ Keith Windschuttle is upset by the 'charge that the British colonisation of this country was a process comparable to the $\mathrm{N}$ azi destruction of the Jews in Europe'. ${ }^{56}$ Earlier, he had expressed his concern about the 'movement on the left' that threatens 'the most far-reaching proposals for the reorganisation and even the eventual break-up of the A ustralian nation'. ${ }^{57}$ M cGuinness al so objects strongly to 'hysterical claims of genocide', 'the bemoaning of the past', and to the intellectuals whom he derides as 'inner-urban ferals'. 58 'The essence of [my] message is that there has been much exaggeration', he continued, 'the invention of charges like genocide and holo-

\footnotetext{
49. Partington 2000.

50. Schmid 2000, Decoust 2000, Romeo 2000, Kiernan 2000.

51. Brunton 1998: 20.

52. Van Krieken 1999.

53. Brunton 1998: 24.

54. Morgan 1999: 12.

55. Sheehan 2001.

56. Windschuttle 2000b: 21 .

57. Windschuttle 2000a: 8

58. McGuinness 2000.
} 
caust has been a matter to impose a kind of moral ascendancy intended to stifle policy debate'. ${ }^{59}$

The intractability of the 'culture wars' in Australia lies in the fact that McGuinness is both right and wrong: the genocide charge, at least for certain episodes of A ustralian history, is true, and it does cede leftist and liberal intellectuals symbolic capital. Such shifts, however, cannot account for the existential fears that such conservatives express. The Mitscherlich account of the relationship between individual and collective identity explains why nationalised subjects experience a loss in self-esteem when the national ego ideal is damaged. In the Australian case, the extremism of statements by Brunton, Morgan and Windschuttle suggests that this analysis should be extended by asking whether such figures experience castration anxiety, that is, a fantasised danger to their genitals symbolised by the national ideal that makes them feel powerful and good about themselves.

5 In yet another similarity with the German experience, when such evidence of genocide, or at least genocidal rhetoric, is uncovered, as in the eugenicist policy announcements of the 1930s, it is placed at the feet of the rival intellectual tradition. 'It is true that some of the policy makers and administrators were in past years motivated by notions of eugenics and Darwinian ranking of races', McGuinness conceded. But with a historical magic wand he determined that 'this was the orthodoxy of the left and the progressive social engineers, not of conservative governments' ${ }^{60}$ The point is not, however, whether conservative or progressive governments instituted such policies, but that they were formulated in the service of a nationalist project of Australian civilisation. It is this continuity for which contemporary conservatism stands and that is now at issue. But McGuinness is impervious to such logic. Any ill that now threatens the nation-building project is automatically split off from his own intellectual commitments and emotional investments. Accordingly, the problems of A borigines today are not the poisoned fruit of two centuries of racism, but of the separatist, anti-assimilationist polices of 'do-gooder' intellectuals and public servants like HC Coombs. And so we end up with surely the most bizarre inversion of the historical scales when McGuinness claims that the 'continual desire to argue that they [A borigines] have been subjected to genocide and are deserving of infinite and eternal compensation' is the 'sophisticated racism' of the white elite. ${ }^{61}$

6) We know that in Germany the consensus about the uniqueness of the Holocaust was only won with the consent of liberals during the 1980s. In a telling parallel, the intellectuals doing the running on the genocide issue in Australia since 1997 have been liberals and left-liberals, in particular the political scientists Robert Manne and Colin Tatz and the philosopher Raimond Gaita. ${ }^{62}$ As editor of Q uadrant, Manne turned the

59. McGuinness 2000b. Phillip Knightley (2000: 107) madethis implausible equation. Quite correctly, no-one else makes this claim: there was no H olocaust in A ustralia.

60. McGuinness 2000a: 2.

61. M cGuinness 1998: 139. Unfortunately, because of limitations of space, I cannot discuss comparative denialism in relation to Robert Manne's analysis of the conservative reaction to the Bringing Them Home report nor deal with Keith Windschuttle's exchanges with Henry Reynolds on frontier violence. For these important controversies, see Manne 2001a, Manne et al . 2001, Gaita 2001a,b, Windschuttle 2000b, 2000c, 2001, Reynolds 2001b, Evans and Thorpe 2001, and Ryan 2001. 
hitherto truculent anti-communist monthly into a lively forum of ideas until he resigned in 1997 after a campaign to oust him by a group of indignant conservatives who accused him of 'selling out' to 'the left'. ers space to reflect on the moral implications of the Mabo decision. Until then, as in Germany in the 1970s, such liberals (or left-liberals, as Gaita regards himself) often sided with conservatives and remained suspicious of the left and its moral weapon, socalled 'political correctness'. ${ }^{64}$ In 1993, for example, Manne was concerned that 'the power of that intellectual movement, which aspires to enforce a dreary political conformity on all matters touching upon race and gender, is growing'. ${ }^{65} \mathrm{He}$ even voted for the Coalition in 1996, and Gaita excoriated 'large parts of the left' for 'foolishness, complacency and intolerance'. .66

Like the German liberals in the 1980s, though, they became less disturbed by leftist academics than the incoming conservative government's counter-politics of memory, in the Australian case, the Coalition's refusal to accept the 'moral basis' of Mabo and reconciliation (as Manne put it), and then with its curt dismissal of the Bringing Them Home report. Its indulgent tolerance of Hanson's racist populism offended their sense that liberal societies are held together by moral restraint. The danger to Australian political culture no longer came from the left and political correctness, Manne concluded, but from the conservatives and their unofficial, covert alliance with the far right. Reviewing Hanson's manifesto, The Truth, Manne held it up to members of the government as a mirror in which to behold their ugly reflection: 'Many will find their own ideas - on the new class, political correctness, Mabo, multiculturalism, Asian migration, the High Court - absorbed, simplified, systematised, and radicalised'. ${ }^{67}$

This change of direction, however, did not mean that Manne has joined 'the left', as his right-wing critics charge. Again, like their German counterparts, such liberals do not criminalise the national past; in fact, Manne emphasises how much of it was admirable. ${ }^{68} \mathrm{~N}$ or do they engage in the politics of guilt. A s early as 1993, Gaita distinguished carefully between the meaning and significance of guilt and shame, entreating the latter as the appropriate response to aspects of Australia's past. ${ }^{69}$ A ccordingly, their posture to the Bringing Them Home report was qualified, rejecting 'morbid self-abasement', encouraging further reflection and research (currently undertaken, among others, by Manne), while urging fellow Australians to bear witness to the suffering that had been inflicted on the victims of the removal policies. ${ }^{70}$ Finally, they reject the post-colonial

62. Tatz has headed a genocide research centre in Sydney since the 1980s, but his major public intervention on this issue was Tatz 1999.

63. Manne 1997b.

64. Manne 1982, 1994.

65. Manne 1993a, b.

66. Manne 1996d: 3, Gaita 1997: 47.

67. Manne 1997a.

68. Manne 2000: 14.

69. Gaita 1993a, b. Manne has consistently referred to these writings and this distinction, see Manne 1996c.

70. Gaita 2000: 171. In a careful, philosophical reflection on the relevant concepts, Gaita (1999) cast doubt on the efficacy of applying genocide to postwar Australia, and he took pains to distinguish between cultural genocide, genocide (according to the UN definition) and the Holocaust. 
answers the Australian left proffers to the Australian past, more sanguine as they are about the possibility of reconciliation, and sceptical about the existence of an identifiable Indigenous collective subject. ${ }^{71}$ 'The Left in Australia now offers enthusiastic support for the ideas of Aboriginal self-determination and land rights', Manne declared, 'but has tended to close its eyes to the depth of social breakdown within the traditional world'. 72

\section{The differences}

Despite these structural similarities, there are four striking differences between the two cases:

1 Unlike Germany, Australia is a settler society, and its genocidal moments are the result of a colonisation process. Strange as it may seem, this fact makes the viability of Australian nationality more precarious than the German one, which long preceded the Holocaust. For in the A ustralian case, the very existence of the nation state and the nationalised subject is predicated on the dispossession, expulsion, and where necessary, extermination of the Indigenous peoples. ${ }^{73}$ This means that the customary conservative ploy of acknowledging the 'dark sides' of an otherwise salutary project is incoherent because the 'dark sides' were intrinsic to the process and cannot be split off. ${ }^{74}$ The survival and eventual prosperity of European settlement depended on the large-scale destruction of A boriginal societies, because the racism of the settlers nearly al ways precluded local negotiations with Indigenous groups and because such groups usually put up stiff resistance when they were not decimated by imported disease. The settlers were at once intrepid farmers and ethnic cleansers, even genocidal killers. They had to be. ${ }^{75}$ The positive myth of origin is at once the negative one.

2 Because Aborigines survived the gamut of policies to assimilate, expel, and exterminate them, and because so many A boriginal individuals and communities live in desperate circumstances, they remain an object of white Australian policy reflection. No comparable issue confronts Germany in relation to Jews, who were a highly integrated and successful minority before National Socialism, and whose population is rapidly growing today due to immigration from Russia.

The current Australian debate is framed rather starkly in terms of integration/ assimilation versus self-determination/ separate development/ treaty. There is no space here to consider these arguments in detail. The task is to determine their significance for the question of 'coming to terms with the past' for the Australian myth of origin. The underlying issue is the prospect of the rival nationalism of pan-A boriginalism, which is necessarily inconsistent with the universalistic pretensions of white A ustralian citizenship. All conservative arguments are mustered to render illegitimate such a project, such as claiming A borigines are incapable of running sophisticated organisations, that they entertain the vain hope of recreating pre-industrial, tribal society, and that their own welfare would be best served by adopting European cultural mores. ${ }^{76}$

\footnotetext{
71. Cf. Povinelli 1998, Hage 2001.

72. Manne 2001c.

73. Barta 1987.

74. Howard 2000.

75. M oses 2000a.
} 
The link between the leftist intelligentsia and Aboriginal nationalism in this debate is certainly clear in the minds of right-wing commentators. The problem, they complain, is the unholy alliance between Aboriginal leaders and leftist intellectuals, supposedly in thrall to a Rousseauean hatred of western civilisation and ridden with 'middle class guilt', who rejoice in the supposed unspoiled harmony of 'primitive cultures' while hypocritically enjoying the accoutrements of urban comfort. Black A rmband scholarship 'has produced a small class of Aboriginal leaders who have been remarkably successful in demanding their own institutions. Their next objective is a treaty that will give them separate political status'. ${ }^{77}$ 'They have abandoned scholarship for politics', Windschuttle complains, 'in a misguided attempt to support Aboriginal demands by defaming the British colonisation of this country'. ${ }^{78}$ The anxiety about the sullied national origins is evident in the conservatives' intemperate rhetorical caricatures of their opponents' argument: 'The only alternative [to assimilation] is the creation of ghettos and zoos, which is what so many of the well-meaning ideologues of multiculturalism and the preservation of "aboriginality" seem to want'. Reconciliation 'pretends that the problem is psychological and moral: rejig the public mind, ask leading political figures to adopt a contrite demeanour and apologise for the sins of history, and all will be well'. ${ }^{79}$

In fact, no one argues that changes in symbolic politics will solve the pressing problems faced by A boriginal communities. But it is a necessary condition for a solution. Left-liberals like Gaita think that historical responsibility and shame entail listening to A boriginal voices and openness to alternative political arrangements. Conservatives retort that such voices (ie the Aboriginal and Torres Strait Islander Commission) are unrepresentative, self-servingly elitist and do not reflect the actual integration of A borigines in the towns and cities. ${ }^{80}$ Gaita responds by saying that it is not up to white Australians to lecture Aborigines about what they should do. ${ }^{81}$ Since there is no one A boriginal voice to which to listen, the question appears to be whether non-Indigenous Australians should support Aboriginal leaders in their efforts to develop pan-Aboriginal consciousness. And as nation-building is driven by elites, a process as much alive in Australia today as in the past, the next question is: which nation-building project should have priority, the European-colonial or the pan-A boriginal one? The alternative slogans 'assimilation' and 'A boriginal sovereignty' are shorthand for these rival nation-building projects.

A quick glance at the literature on the emancipation of German Jews shows this to be a fal se dichotomy, because it does not capture the complexity of German Jews' integration in Germany in the nineteenth century. For the hybridised identity they created issued from a process of acculturation in which Jews developed a distinct sub-culture that retained an emphatic sense of Jewishness as well as of Germanness. ${ }^{82}$ Similarly, in

76. Arndt 2001, Duffy 2001a, Johns 2001, Howson 1999 and 2000, Sandall 2001, Samuels 2000, Windschuttle 2000a.

77. Duffy 2001a.

78. Windschuttle 2001b.

79. McGuinness 2000a: 3, Sandall 2001,

80. Brunton 1997, Windschuttle 2001a, Sandall 2001.

81. Gaita 2000.

82. Sorkin 1987. 
Australia, we are dealing not with the anachronistic retention of pre-modern 'A boriginality', as many conservatives suggest (McGuinness's 'zoos and ghettos'), but with the acculturation of Indigenous peoples in which they develop a hybrid culture of their own.

Moreover, the hobgoblin of a 'break-up of Australia' does not appear to be on the agenda of Indigenous leaders like Geoff Clark. In calling for a treaty, he declares that he is not 'talking of two nations'. He sees such a document, and the process by which it is generated, as making good the 'unfinished business' of the country's foundation, namely the absence of symmetrical negotiations in 1788 in which 'they [the British] should have sought the informed consent of the indigenous peoples to inhabit this country'. ${ }^{83}$ This is not a case, then, of a separate A boriginal state, but of renegotiating the terms of the original settlement. This process sounds very much like the openended hermeneutical comportment to national traditions after the rupture of the national myth of origin by the perpetrator trauma.

3 Unlike Germany, however, progressive philosophies of history that redeem suffering - theodicies - have not been discredited. As Blainey articulated clearly in 1993, conservatives must hold fast to a theodicy to redeem the undeniable suffering caused by the march of the progress on which they set so much store. With endearing candour, they recognise that A boriginal societies had to give way before the superior British alternative. Were A borigines to survive at all, so the argument runs, they had to adopt the white man's ways, thereby conceding the illiberal and potentially exterminatory potential at the heart of western civilisation. ${ }^{84}$ In a notably unguarded statement, the former anthropology lecturer Roger Sandall goes so far as to admit that 'Western Culture' (his words) advances by 'creatively destroying' obsolete traditions, and he advocates the same work of destruction for A boriginal culture today. ${ }^{85}$

A ustralian liberals and leftists will have none of this, because, like contemporary Germans, their comportment to history has been transformed by the Holocaust. After all, Australian intellectuals do not debate issues of race and nationalism in a historical vacuum. The Holocaust exerts its presence here in the form of large survivor communities, Jewish organisations, intellectuals of Jewish descent, and its seepage into popular cultural memory since the 1970 s through films, books, and war crimes trials. Discourse about the Holocaust provides a range of terms like 'the banality of evil' and genocide 'denial' that frame the Australian history wars. ${ }^{86}$ For our purpose, the significant issue is that it has become the secular symbol of evil in the western world, a status that has had a signal bearing on the genocide debate. For, from one perspective, the uniqueness of the Holocaust can mean that events that do not resemble it are not genocidal at all. ${ }^{87}$ Such an understanding drove the Federal government's denial of the Stolen Generations and Inga Clendinnen's attack on the application of the genocide concept to

\footnotetext{
83. Clark 2001b.

84. Samuels 2000.

85. Sandall 2001. The Bennelong Society writes of 'the destruction of the old', Partington 2000.

86. Levey 2001, Curthoys 2001, Tatz 1997.

87. This interpretation of the Holocaust is the target of Peter Novick's The H ol ocaust in A merican Life, 1999.
} 
Australian history. ${ }^{88}$ Others, though, find another message in the Holocaust, recently articulated in elegant terms by Martin Jay:

Historicising the Holocaust need not mean reducing it to the level of the 'normal' massacres of the innocents that punctuate all of recorded history, but rather remembering those quickly forgotten and implicitly forgiven events with the same intransigent refusal to normalize that is the only justifiable response to the Holocaust itself. ${ }^{89}$

Behind this careful balancing of the particular and universal in the Holocaust stands the historical philosophy of the German critic Walter Benjamin. To arguments that western culture advances by creative destruction, Benjamin pointed out that such historicism and theodicies view the past through the eyes of the victors and retrospectively justify their actions and morality. He urged anamnestic solidarity with the victims today as a way of interrupting the supposed ineluctable and necessary process of civilisation: 'There is no document of civilisation which is not at the same time a document of barbarism'. ${ }^{90}$ Benjamin articulates the perpetrator trauma, and he exemplifies the suspicion many intellectuals now have of theodicies. In this mode, the Holocaust is neither sacralised nor banalised - the twin dangers highlighted recently by Tzvetan Todorov $^{91}$ - and assumes the status of a moral source with which to combat all forms of racism.

This was the interpretation adopted by Manne in the Demidenko debate in 1996, which was essentially about whether the Holocaust would be inscribed into A ustralian public culture as such a source. 'A re we not too part of that common civilisation which experienced the shock of Auschwitz and which internalised its meaning?', he asked. ${ }^{92}$ In his review of Manne's book on the debate, the conservative commentator Frank Devine effectively denied that we were, or indeed that we should be. ${ }^{93}$ Fellow columnist Michael Duffy agrees, concerned as he is at the 'growing influence of people, Jewish and non-Jewish, with a particular interest in the Nazi Holocaust'. Desperate to avoid charges of anti-Semitism, he acknowledges that because many Jews have fresh memories of 'victimisation and suffering' they 'may be able to view the situation of A borigines with greater clarify and compassion' than other A ustralians. Yet the dangers of this H olocaust paradigm is the point of his article, tellingly entitled ' $\mathrm{Keep}$ the $\mathrm{H}$ word out of our history'. ${ }^{94}$ Manne's Holocaust-inflected Jewish 'preconceptions', Duffy insinuates, are 'damaging the truth'. ${ }^{95}$ It is no coincidence that the intellectual camps at war over the Demidenko book are by and large the same as those in the genocide debate.

88. Howard was prepared to 'express his sorrow and distress at the appalling tragedy which overcame the Jewish people', but no more than 'regret' at what previous Australian governments had done to A borigines: Grattan, Kerr, and M etherell 2000; Clendinnen 2001. This is also the editorial position of the Courier M ail (Brisbane): Courier M ail 2001. Cf. Gaita 1999: 110.

89. Jay 1998: 204, cf. Gaita 1995.

90. Benjamin 1968: 256.

91. Todorov 1996.

92. Manne 1996b: 15, Manne 1996a.

93. Devine 1996.

94. Duffy 2000.

95. Duffy 2001b. Manne 2001b talks of his youth as the child of refugee central European Jewish parents in his Deakin Lecture. 
There is no consensus on Holocaust consciousness in Australia, and it is readily apparent in the differing attitudes towards pan-A boriginal political consciousness.

\section{Conclusion}

The German case shows that political humanisation issues from an open-ended discussion in a public sphere where the taboos of national myths of origin have been shattered by a consensus among leftist and liberal intellectuals about the need to thematise the barbarism inherent in those origins. At the same time, no factions of the intelligentsia, particularly the left- and right-wing factions with their absolute answers to 'the past', are able to impose themselves. Such a public sphere is the basis of a 'self-critical community' and it permits the problems highlighted by the perpetrator trauma to be addressed against an open horizon about the meanings of the past.

So does Australia have anything to learn from the German experience? The answer to this question depends on whether the similarities between the two cases are more significant than the differences. There are good reasons to suppose that they are. Australia shares the basic problem of national myths of origin and the consequent perpetrator trauma and process of political humanisation it inaugurates. Australia certainly needs to become a 'self critical community'. The differences are significant only for the specific problems that such a process must address. In Germany, the perpetrator trauma continues until the grounds for indignation about the past are addressed: compensating the victims of Nazism, ending racist violence against non-Europeans, liberalising the naturalisation laws. In Australia, it will al so haunt future generations until Indigenous Australians can flourish here as well as any non-Indigenous Australian. We do not know what such a future society will look like: the point of political humanisation is to include relevant social stakeholders in the public conversation. A good start will have been made when Aborigines are not discussed as objects of white policy.

\section{Acknowlegments}

My thanks go to the editors, the anonymous referee, Adrian Carton, Andrew Dowling, Simone Gigliotti, Ghassan Hage, Claire Hooker, Duncan Ivison, and Geoffrey Brahm Levey for helpful comments on drafts, and to the stimulating students of my 'historical revisionism' honours seminar in 2001.

\section{References}

Adam, Heribert 2001, 'Divided memories: confronting the crimes of previous regimes', Telos, 118: 87-108.

Albrecht, Clemens et al. 1999, D ie intellektuelle Gründung der Bundesrepublik. Eine W irkungsgeschichte der Frankfurter Schule, Frankfurt and New York.

A ppiah, Kwame Anthony 1997, 'Cosmopolitan patriots', Critical Inquiry, 23: 617-39.

Arndt, Bettina 2001, 'A culture of denial', Sydney M orning H erald, 26 A pril: 11.

Assmann, Jan 1997, M oses the Egyptian: the memory of Egypt in W estern monotheism, Cambridge, Massachusetts.

1999, 'Tagtraumdeutung', F ran kfurter A llgemeineZ eitung, 1 July: 48.

Attwood, Bain 1996, 'Mabo, A ustralia and the end of history', in Bain Attwood (ed.), In the age of M abo: history, A borigines and A ustralia, Sydney: 100-16. 
2000, 'All Australians would gain from a treaty', The A ustralian, 8 June: 15.

2001, 'A tour of duty in Australia's history wars', A ustralian Financial Review, 1 June: 8 .

Balibar, Etienne 1991, 'The nation form: history and ideology', in Etienne Balibar and Immanuel Wallerstein (eds), Race, nation, class: ambiguous identities, London: 86106.

Barkan, Elazar 1999, The guilt of nations: restitution and negotiating historical injustices, New York.

Barta, Tony 1985, 'A fter the Holocaust: consciousness of genocide in Australia', A ustralian Journal of Politics and History, 31: 154-61.

1987, 'Relations of genocide: land and lives in the colonization of A ustralia', in Isidor Walliman and Michael N. Dobkowski (eds), Genocide and the modern age: etiology and case studies of mass death, New York: 237-51.

_ 1989, 'Anti-Fascism and democracy in Dachau, 1945', in Isidor Walliman and Michael N. Dobkowski (eds) Radical perspectives on the rise of Fascism in Germany, 1919-1945, N ew York: 289-318.

Bartrop, Paul B. 2001, 'The Holocaust, the Aborigines, and the bureaucracy of destruction: an Australian dimension of genocide', J ournal of G enocide R esearch, 1: 75-87.

Baruma, Ian 1994, The wages of guilt: memories of war in Germany and Japan, New York.

Beilharz, Peter 2001, 'Australian civilization and its discontents', Thesis Eleven, 64: 6576.

Bernstein, Richard 1998, Freud and the legacy of M oses, Cambridge.

Bhabha, Homi K. 1990, 'Introduction: narrating the nation', in Homi K. Bhabha (ed.) $\mathrm{N}$ ation and narration, London and New York: 1-7.

_ 1998, 'Foreword: Joking aside: the idea of a self-critical community', in Bryan Cheyette and Laura Marcus (eds) M odernity, culture, and 'the Jew', Cambridge: Xv$x$.

Blainey, Geoffrey 1993, 'Drawing up a balance sheet of our history', Q uadrant, Jul-Aug: $10-15$.

2000, 'Three cheers for the little nation that could', The A ustralian, 13 Nov: 13.

Bosworth, R.J.B. 1993, Explaining A uschwitz and Hiroshima: history writing and the Second World War 1945-1990, London.

Bourdieu, Pierre 1977, 0 utline of a theory of practice, Cambridge.

_ 1984, D istinction: a social critique of the judgement of taste, Cambridge, Massachusetts.

1987, 'What makes a social class?', Berkeley Journal of Sociology, 32: 1-17.

1988, H omo A cademicus, Stanford.

1998, Practical reason, Cambridge.

Brunton, Ron 1997, 'Shame about A borigines', Q uadrant, May: 36-9.

__ 1998, 'Genocide, the "Stolen Generations", and the "unconceived generations"', Quadrant, May.

2000, 'Justice O'Loughlin and Bringing them Home: a challenge to the faith', Quadrant, Dec: 37-42. 
2001, 'Correcting the False Scholarship Syndrome', Institute of Public A ffairs website: http:/ / www.ipa.org.au/ Reply/ falsescholar.html

Carlyon, Patrick 2001, 'Whitelies', The Bulletin, 12 Jun: 26-30.

Caruth, Cathy (ed.) 1995, Trauma: explorations in memory, Baltimore and London.

Cassrels, Deborah 2001, 'A ustralian genocide, part 8', Courier M ail, 4Jun.

Clark, Geoff 2001a, 'This white nation is slow to change', The A ge, 9 May.

_ 2001b, 'A treaty would unite, not divide', A ustralian, 19Jun: 11.

Clark, Manning 1988, 'The beginning of wisdom', Time A ustralia, 25 Jan: 12-5.

Clendinnen, Inga 2001, 'First Contact', A ustralian's R eview of Books (May): 6-7, 26.

Courier M ail 2001, Editorial: 'Time to stop the real genocide', Courier M ail, 7 A pril: 24.

Curthoys, Ann 1999, 'Expulsion, exodus and exile in White A ustralian historical mythology', Journal of A ustralian Studies, 61: 1-19.

Curthoys, N ed 2001, 'The politics of Holocaust representation: the worldly typologies of Hannah A rendt', A rena J ournal, 16: 49-74.

Davis, Mark 1999, Gangland: cultural elites and the new generationalism, 2nd edn, Sydney.

Decoust, Michele 2000, 'Die verlorenen Kinder der Aborigines', D ie Tageszeitung, 13 Oct.

Devine, Frank 1996, 'Review of Robert Manne, The culture of forgetting' in Q uadrant, JulAug: 94-6.

Devine, Miranda 2001, 'Some issues are not just black and white', Sydney M orning H erald, 5Jul: 10.

Diner, Dan 1993, V erkehrteW elten. A ntiamerikan ismus in D eutschland, Frankfurt am Main.

Duffy, Michael 2000, 'Keep the H word out of our history', D aily Telegraph, 5Jan: 10. 2001a, 'Black and white conceits', W eekend A ustralian, 26-27 May: R14.

2001b, 'Who's sorry now?', Courier M ail, 7 Jun.

Duncan, Tim 1985, 'A boriginal genocide theory lacks evidence', Bulletin, 5 Feb: 28-30.

Eley, Geoff (ed.) 2001, The 'Goldhagen effect': history, memory, N azism - facing the German past, Ann Arbor.

Eliade, Mircea 1963, M yth and reality, New York.

Evans, Ray and Thorpe, Bill 2001, 'Indigenocide and the massacre of A boriginal history', 0 verland, 163 (Jul): 18-34.

Frei, N orbert 1999, V ergangenheitspol itik. D er Anfänge der Bundesrepublik und die N S- V ergangenheit, Munich.

Foucault, Michel 1984, 'What is enlightenment?' in Paul Rabinow (ed.), The Foucault reader, N ew York: 32-50.

Fulbrook, Mary 1999, German national identity after the $\mathrm{H}$ olocaust, Cambridge.

Gaita, Raimond 1992, 'Racism', Q uadrant, Jul-Aug: 54-6. 1993a, 'M abo (part one)', Q uadrant, Sept: 36-9.

1993b, 'Mabo (part two)', Q uadrant, Oct: 44-8.

1995, 'Remembering the Holocaust: absolute value and the nature of evil', Q uadrant, Dec: 7-15.

1997a, 'N ot right', Q uadrant, Jan-Feb: 46-51. 
1997b, 'Genocide and pedantry', Q uadrant, Jul-A ug: 41-5.

1998, 'Reply to Kenneth Minogue', Q uadrant, N ov: 39-43.

1999, A common humanity: thinking about love and truth and justice, Melbourne.

2000, 'Who speaks, about what, to whom, on whose behalf, with what right?' in Peter Craven (ed.), Best A ustralian Essays, Sydney: 162-76.

_ 2001a, 'Exposing the shabby', The A ge, 13 A pril.

2001b, 'Why the impatience? Genocide, 'ideology' and practical reconciliation', A ustralian Book Review, Jul: 25-31.

Galtung, John 1990, 'Cultural violence', J ournal of Peace Research, 27: 291-305.

Geisen, Bernard 1998, Intellectuals and the German nation, Cambridge.

Geyer, Michael 1996, 'Politics of memory in contemporary Germany', in Joan Copjec (ed.), Radical evil, London: 169-200.

Goldhagen, Daniel Jonah 1997, 'M odell Bundesrepublik: national history, democracy and internationalization in Germany', Common Knowledge, 3: 10-18.

Golsan, Richard J. (ed.) 1996, M emory, the H olocaust and French justice, Hanover and London.

Gooder, Haydie and Jacobs, Jane M. 2000, 'On the border of the unsayable', Interventions, 2: 229-47.

Gouldner, Alvin W. 1979, The future of intellectuals and the rise of the new class, New York.

Habermas, Jürgen 1989, The new conservatism: cultural criticism and the historians' debate, Cambridge, Massachusetts: 229-40.

1990, M oral consciousness and communicative action, Cambridge, Massachusetts.

1996, 'On how postwar Germany has faced its recent past', Common Knowledge, 2: $1-13$.

_ 1997, 'On the public use of history: why a “democracy prize” for Daniel Goldhagen', Common Knowledge, 3: 2-9.

Hage, Ghassan 1998, White nation: fantasies of White supremacy in a multicultural society, Sydney.

_ 2000, 'On the ethics of pedestrian crossings,' M eanjin, 4: 27-37.

2001, 'Polluting memories: migration and colonial responsibility in Australia', Traces, 2 (Sept).

Heer, Hannes and Naumann, Klaus 2000, War of extermination: the German military in W orld W ar II, 1941-1944, New York.

Henderson, Gerard, 'The Howard view of history', Sydney M orning H erald, 4 A pr.

Herbert, Ulrich 1999, 'A cademic and public discourses on the Holocaust: the Goldhagen debate in Germany', German Politics and Society, 3: 35-53.

Herf, Jeffrey 1997, Divided memory: the $N$ azi past in the two Germanys, Cambridge.

Hirsch, Herbert 1995, Genocide and the politics of memory: studying death to preserve life, Chapel Hill.

Howard, John 1996a, 'Confront our past, yes, but let's not be consumed by it', The A ustralian, $19 \mathrm{Nov}$.

1996b, 'PM Slams Keating on race speech', The A ustralian, 13N ov. 
2000, 'Towards a common destiny', Sydney M orning H erald, 12 May: 13.

Howson, Peter 1999, 'Rescued from the rabbit burrow: understanding the "Stolen Generation,"', Q uadrant, Jul: 10-14.

2000, 'Reality and fantasy: the abject failure of A boriginal policy', Q uadrant, A pr: 20-24.

Hurm, Gerd 1999, 'Community, commitment, and criticism: the rhetorical embeddedness of Michael Walzer's communitarian theory' in Roland Hagenbüchle and Josef Raab (eds), N egotiations of A merican national identity, Tübingen: 368-85.

Ivison, Duncan 2000, 'Political community and historical injustice', A ustralasian Journal of Philosophy, 3: 360-73.

Jay, Martin 1973, The Dialectical imagination: a history of the Frankfurt School and the Institute for Social Research, 1923-1950, Boston.

1998, Cultural semantics: keywords for our time, Amherst.

Johns, Garry 2001, 'The failure of A boriginal separatism', Q uadrant, May: 9-18.

Keating, Paul 1995, ed. Mark Ryan, A dvancing A ustralia: the speeches of Paul Keating, Prime M inister, Sydney.

Kiernan, Ben 2000, 'Australia's A boriginal genocide', Bangkok P ost, 10 Sept.

Klein, Kerwin Lee 2000, 'On the emergence of memory in historical discourse', Representations, 69: 127-50.

Knightley, Phillip 2000, A ustralia: a biography of a nation, London.

LaCapra, Dominick 2001, W riting history, writing trauma, Ithaca and N ew York.

Levey, Geoffrey Brahm 2001, 'Reconciliation and "the banality of evil'", A ustralian Financial Review, 6Jul (Review Section): 4f.

Lewis, Alison, 1995, 'A nalyzing the trauma of German unification', N ew German Critique, 64: 135-60.

Maier, Charles S. 1988, The unmasterable past: history, H olocaust and German national identity, Cambridge, Massachusetts.

1993, 'A surfeit of memory? Reflections on history, melancholy and denial' H istory and $M$ emory, 136-51.

Manne, Robert (ed.) 1982, The new conservatism in A ustralia, Melbourne.

Manne, Robert 1993a, 'On political correctness', Q uadrant, Jan-Feb: 2f.

__ 1993b, 'The hidden face of freedom of speech', Sydney M orning H erald, 9 Aug: 17. 1994, The shadow of 1917: the cold war conflict in A ustralia, Melbourne. 1996a, The culture of forgetting: $\mathrm{H}$ elen D emiden ko and the $\mathrm{H}$ ol ocaust, Melbourne. 1996b, 'The Demidenko affair: free speech and political correctness', Q uadrant, Jun: 8-15.

_ 1996c, 'Forget the guilt, remember the shame', The A ustralian, 8 Jul: 11. 1996d, 'Editorial: The Coalition and the A borigines', Q uadrant, Sept: 3f. 1997a, 'Paranoid party manifesto', review of 'Pauline Hanson: the truth', Q uadrant, Jun: 85f.

_ 1997b, Editorial: 'Why I have resigned', Q uadrant, Dec: $2 f$.

__ 1998, The way welive now: the controversies of the nineties, Melbourne. 
2000, 'H onesty is the best Federation policy', Sydney M orning H erald, 20 Nov: 14. 2001a, 'In denial: theStolen Generations and the Right', A ustralian Q uarterly Essay, 1. 2001b, 'My country - a personal journey', Deakin Lecture, Melbourne, 20 May 2001, unpublished ms.

2001c, 'Charting a new course for Black survival', Sydney M orning H erald, 16Jul: 22.

Manne, Robert et al. 2001, 'In denial: Correspondence', A ustralian Q uarterly Essay, 2.

Marcuse, Harold 1998, 'The revival of Holocaust awareness in West Germany, Israel, and the United States', in Carol Fink, Philipp Gassert and Detlef Junker (eds), 1968: the world tran sformed, Cambridge: 421-38.

_ 2001, Legacies of D achau: the uses and abuses of a concentration camp, 1933-2001, Cambridge.

McAdams, A. James (ed.) 1997, Transitional justice and the rule of law in new democracies, Notre Dame, Indiana.

McGuinness, Padraic P. 1998, 'The political elites' contribution to Hansonism', in Tony A bbott et al. (eds), Two nations, Melbourne: 131-40.

_ 2000a, 'Assimilation, Christians, and the Vicar of Bray', Q uadrant, Jun: 2-4.

_ 2000b, 'A boriginal history: Black and Whiteviews won't do', The A ustralian, 16 Nov: 18.

_ 2001, 'This talkfest is not on the road to reconciliation', Sydney M orning H erald, 15 Feb: 14.

McKenna, Mark 1997, 'The Black-armbandwagon', Eureka Street, 7: 17-19.

Markus, A ndrew 1996, 'Between Mabo and a hard place: race and the contradiction of conservatism', in Bain Attwood (ed.), In the age of M abo: history, A borigines and A ustralia, Sydney: 88-99.

2001, Race: John H oward and the remaking of A ustralia, Sydney.

Milner, Andrew 2000, 'Class and cultural production', A rena Journal, 15: 117-37.

Minogue, Kenneth 1998, 'A borigines and A ustralian apologetics', Q uadrant, Sept: 11-20.

Minow, Martha 1998, Between vengeance and forgiveness: facing history after genocide and mass violence, Boston.

Mitscherlich, Alexander and Margarete 1975, The inability to mourn: principles of collective behavior, New York.

Moeller, Robert 2000, War stories: the search for a usable past in the F ederal Republic of Germany, Berkeley.

Morgan, Patrick 1999, 'The end of fortress A ustralia', The A delaide R eview, Sept.

Moses, A. Dirk 1998a, 'Structure and agency in the Holocaust: Daniel J. Goldhagen and his Critics', $H$ istory and Theory, 2: 194-219.

1998b, 'The state and the student movement, 1967-1977', in Gerard de Groot (ed.) Student protest: the sixties and after, London: 139-49.

_ 1999, 'The Forty-Fivers: a generation between fascism and democracy', German Politics and Society, 1: 95-127.

_ 2000a, 'An antipodean genocide? The origin of the genocidal moment in the colonization of Australia', Journal of Genocide Research, 1: 89-105.

_ 2000b, 'Right's historical wrongs, The A ustralian, 19Jul: 38. 
Muller, Jerry Z. 2000, 'German neoconservatism and the history of the Bonn Republic, 1968-1985', German Politics and Society, 1 (Spring): 1-32.

Müller, Jan-Werner 2000, A nother country: German intellectuals, unification and national identity, New Haven.

Nauman, Michael 2000, 'Remembrance and political reality: historical consciousness in Germany after the Genocide', N ew German Critique, 80 (Spring-Summer): 17-28.

Novick, Peter 1999, The H olocaust in A merican life, N ew York.

Olick, Jeffrey K. 1998, 'What does it mean to normalize the past? Official memory in German politics since 1989', Social Sciences H istory, 22: 547-71.

1999, 'Collective memory: the two cultures', Sociological Theory, 3: 333-48.

and Coughlin, Brenda, forthcoming, 'The politics of regret: analytical frames', in John B. Torpey (ed.), The politics of the past: repairing historical injustices, N ew York.

_ and Levey, Daniel 1997, 'The Holocaust: collective memory and cultural constraint', A merican Sociological Review, 6: 921-37.

__ and Robbins, Joyce 1998, 'Social memory studies: from "collective memory" to the historical sociology of mnemonic practices', A merican Review of Sociology, 24: 10540.

Partington, Geoff 2000, 'The origins of the Bennelong Society: an evaluation of a workshop: A boriginal policy failure, reappraisal and reform', www.bennelong.com.au.

Patton, Paul 1995, 'Mabo, freedom and the politics of difference', A ustralian Journal of Political Science: 109-19.

Postema, Gerald 1991, 'On the moral presence of our past', M cGill Law Journal, 4: 115380.

Povinelli, Elizabeth A. 1998, 'The state of shame: A ustralian multiculturalism and the crisis of Indigenous citizenship', Critical Inquiry, 24: 575-610.

Reynolds, Henry 2000, 'The public role of history', Dissent, 3 (Spring): 2-5.

_ 2001a, 'From armband to blindfold', A ustralian's R eview of Books, Mar: 8-9, 26. 2001b, A $n$ indelible stain? The question of genocide in Australia's history, Sydney.

Romeo, Antonella 2000, 'Die geraubte Generation', D ie Z eit, 23, 13 May: 15f.

Ryan, Lyndall 2001, 'Postcolonialism and the Historian', A ustralian $\mathrm{H}$ istorical A ssociation Bulletin, 92(Jun): 31-7.

Samuels, Gordon 2000, 'One past, one future for us all', The A ustralian, 15 N ov: 13.

Sandall, Roger 2001, 'Romancing the Stone A ge', Sydney M orning H erald (Spectrum), 12 13 May: $2 f$.

Schaap, Andrew 2001, 'Guilty subjects and political responsibility: A rendt, Jaspers and the resonance of the 'German question' in politics of reconciliation', Political Studies, 49: 749-66.

Schelsky, Helmut 1975, 'D ie A rbeit tun die A nderen': Klassenkampft und Priesterherrschaft der Intellektuellen, Opladen.

Schmid, Thomas 2000, 'A ustraliens Holocaust', Die Z eit, 23 (13 May): 78.

Schwan, Gesine 2001, Politics and guilt: the destructive power of silence, Lincoln.

Sheehan, Paul 2001, 'Saved, not stolen: laying the genocide myth to rest', Sydney M orning H erald, 4Jul: 22. 
Smith, Bernard 1981, The spectre of Truganini, Sydney.

Sontheimer, Kurt 1976, D as Elend unserer Intellektuellen, Hamburg.

Sorkin, David 1987, The transformation of German Jewry, 1780-1840, Oxford.

Sydney M orning Herald 1993, Editorial: 'Fischer and the A borigines', 9 Aug.

Tat, Colin 1997, 'Genocide and the politics of memory', Genocide Perspective I, Sydney: 308-58.

1999, G enocide in A ustralia, AIA TSIS Research Discussion Paper no 8, Canberra.

Todorov, Tzvetan 1996, 'The abuses of memory', Common Knowledge, 1: 6-26.

Van Krieken, Robert 1999, 'The barbarism of civilization: cultural genocide and the 'Stolen Generations', British Journal of Sociology, 2: 295-318.

Villa-Vicencio, Charles and Verwoerd, Wilhelm (eds) 2000, Looking back, reaching forward: reflections on the Truth and Reconciliation Commission of South A frica, London.

Walzer, Michael 1987, Interpretation and social criticism, Cambridge, Massachusetts.

Watson, Don 2000, The politics of history (or the history of politics), History Council of N SW Annual Lecture, Sydney.

Webber, Jeremy 1995, 'The jurisprudence of regret: the search for standards of justice in Mabo', Sydney Law Review, 17: 5-28.

W eekend A ustralian 2001, Editorial: 'Undignified debate clouds reconciliation', 7-8 A pr: 18.

Wiedmer, Caroline 1999, The claims of memory: representations of the H olocaust in contemporary Germany and France, Ithaca and London.

Windschuttle, Keith 1994, The killing of history: how a discipline is being murdered by literary critics and social theorists, Sydney.

__ 2000a, 'The breakup of Australia', Q uadrant, September 2000: 8-18. $2000 \mathrm{~b}$, 'The myths of frontier massacres in Australian history (part I)', Q uadrant, Oct: 8-21.

2000c, 'The myths of frontier massacres (part II)', Q uadrant, N ov: 17-25.

2001, 'Selected readings I', A ustralian's Review of Books, A pr: 5.

Wilson, Charles 1985, 'History, hypothesis, and fiction: small pox and Aboriginal genocide', Q uadrant (Mar): 25-32.

Wipperman, Wolfgang 1976, 'The post-war German left and fascism', Journal of Contemporary History, 11: 185-219. 